\title{
Experiences and Reimaginings of Development from a Kutchi Village
}

\author{
Lyla Mehta
}

Abstract This article asks how the global financial crisis (GFC) affected rural communities in western India that have always lived with crises. A visit to Kutch, a border district in Gujarat, revisited after seven years, revealed that the GFC was not very present in the lives of the general population and there was very little radical reimagining of development. Despite impressive post-earthquake reconstruction, massive improvements in infrastructure and a rapid growth rate, there appeared to be very few changes to age-old, feudal, caste and gender inequalities. Economic development had not translated to human development and there remain several ecological unknowns and potential negative impacts in terms of long-term environmental sustainability.

\section{Introduction}

This article explores how the global financial crisis (GFG) affected communities that have always lived with crises. Does it provide an opportunity to create ways to reimagine development that could make it more just and sustainable or does it not make any difference? To answer these questions, I revisited Merka, a village in Kutch (see Box 1), a border district in the state of Gujarat in western India. I first went to Kutch in 1995 and spent a year there as part of my doctoral research and I have returned six times since.

Why is Kutch an interesting place in which to ask questions about crises, development alternatives and reimagining? Water, climate and resource crises are not new to Kutch, a region that is constantly subjected to uncertainty, owing to its highly variable rainfall and turbulent geology (Mehta 2005). Kutch has an arid to semi-arid climate and is considered to be a drought-prone district. Droughts take place every two to three years. Its long coastline is often struck by cyclones and it is also highly earthquake prone. A devastating earthquake in 2001 claimed about 14,000 lives. Due to extreme events and its rapidly changing environment, many livelihoods are changing and some traditional livelihoods are becoming unviable. Thus, there is an ongoing need to conceive of locally appropriate ways to deal with dynamic environmental change and uncertainty.

As part of the Reimagining Development initiative, I spent five days in Kutch during May 2010. In the capital, Bhuj, I spoke to bank officials, journalists, writers, academics, retired politicians, NGO workers and academics and also ordinary women and men (homemakers, rickshaw drivers and workers). I spent three days in the village of Merka where I interacted with a cross-section of people (women and men from different castes and religions and across different occupations, i.e. pastoralists, farmers and landless workers), many of whom are old friends. All of them have lived with and known a range of crises.

When I embarked on this project, I had assumed that the GFC would add new challenges to the existing crises. Instead, I was surprised that there was hardly any talk of new globally induced 'crises'. I witnessed many changes in the region on my return. The post-earthquake reconstruction was very impressive, alongside widespread industrial development and massive improvements in infrastructure. Gujarat has a growth rate of about 12 per cent and some parts of Kutch are truly engines of this growth rate. Still, the long-term environmental and social sustainability of this growth remains 
Merka is a village in eastern Kutch, a border district of Gujarat in western India. It has a population of 5,000 people and is largely a Hindu multi-caste village with a small Muslim minority. It has retained its erstwhile feudal character with sharp distinctions still existing between so called 'high' and 'low' castes. The main village square is about $4 \mathrm{~km}$ away from a major highway connecting Kutch with Gujarat. The far end of the village is located on the edge of the Little Rann of Kutch, arid salt marshlands. Desert-like conditions have moulded life in this village. Merka's residents engage in dryland and some irrigated agriculture, migratory pastoralism and daily wage labour.

Kutch is the largest district in Gujarat, constituting 23 per cent of the state. It has a population of 1.5 million. Rainfed agriculture and animal husbandry are the chief bases of livelihoods in Kutch, though in recent years it has become a haven of mineral and industrial development and is home to many special economic zones (SEZs).

questionable. I found very little alternative thinking or reimagining of development among the general population. There also appeared to be very few changes to age-old, feudal, caste and gender inequalities. Instead, it appeared as though inequality and the marginalisation of certain social groups were on the rise.

\section{Responses to the global financial crisis (GFC)}

Various literature on the GFC suggests that many people in the global South have coped better with shocks than many in the global North (Green et al. 2010). The GFC has also been ever-present in the media in the global North, but it is not so in Kutch. In the village of Kutch, nobody had heard about the GFC. A Dalit woman told me: 'We eat, work and sleep as usual. There have been no significant changes in our life'. The middle-class and educated people I spoke to in Bhuj, the capital city, had heard of it, but saw it as something that was largely affecting the global North. A retired lawyer and former politician said: 'This crisis is largely due to the irresponsible behaviour of western Banks and most of its impacts are felt in the West. Our Reserve Bank has been more cautious than Western banks. Moreover, Kutch as a region does not know financial crises'. This quote may appear jingoistic to some, however, it indicates that in Gujarat - like in other parts of India - there is a feeling that the GFC both originated in and was largely affecting the North. (Of course, knock-on effects may take a while to be felt and 2010 may have been too soon for local level impacts to hit.) Still, some background on Kutch's financial situation may explain why Kutch does 'not know financial crises'.
Many Kutchi communities are well known for their commercial enterprise, especially in the diaspora. Kutch has no abundant or perennial rivers that can support flourishing agricultural systems. Thus, the region has had to rely on dryland agriculture and pastoralism (both highly adaptable to the semi-arid climate), industry, mining, business and outmigration. Since time immemorial, Kutchis have migrated out of the region to distant lands (Bombay, East Africa, the UK). These migrant Kutchis have sent home remittances and Kutchis have fostered a tradition of saving. Kutchi banks have some of the highest levels of deposits and savings in India. I was told by an employee of the State Bank of India that this situation has not changed for Kutch since the financial crisis.

It would, however, be foolish to assume that this situation characterises all Kutchis. There is a vast difference between commercial areas where the financial downturn has not set in and remote rural areas. In Merka, most residents live a handto-mouth existence building up surpluses of grain, money and fodder in good years and drawing them down in bad years. The crisis narratives that I heard on this trip were the same as those I had heard in the past. People complained about the lack of regular employment, the dependence on migration as a livelihood strategy, the lack of irrigation facilities, and the low, unpredictable and variable rainfall and frequent droughts to which I soon turn.

India's growth rate was recorded at 8.8 per cent in the second half of 2010, the highest rate since the onset of the GFC (Buncombe 2010). Gujarat was seen to lead this development with a record 
growth rate of about 11-12 per cent for the past five years (Bhat undated). It is believed that good farm and manufacturing output led to putting the country back on the trajectory it was on before the recession (prior to the GFC, its growth averaged nearly 9 per cent, though it did dip to 6 per cent in 2009; Buncombe 2010). Still, the benefits of this growth have largely been restricted to the rich and middle classes. The poor have also been hurt by inflation in 2010, despite the assertions of many that India has not been affected by the GFC (see McGregor, this IDS Bulletin, for an analysis of how it is difficult to separate out the different impacts of recent crises). A total of 600 million Indians who live on less than \$2-a-day spend a high proportion of their income on food, and this has seen massive price rises. In Merka, people acknowledged rising food and commodity prices in the recent past. I was told: 'Sugar used to cost Rs 16 per kilo and now it costs Rs42. Bajra (pearl millet) now costs Rs 12 and it used to cost Rs7 only two years ago'. It would thus be safe to say that while Merka's residents had not heard of the crisis, they were feeling the impacts of rising food prices. Many people, however, said that average incomes had gone up (even of casual labourers in the village, from Rs50 to Rs 100). They also acknowledged the massive changes to their lives since the 2001 earthquake.

\section{Post-earthquake developments}

The earthquake of 2001 truly devastated the region. It brought about an influx of outsiders, donors, aid workers into what was hitherto a remote region. I went back twice after the earthquake to meet people and got involved in relief activities. Merka's isolation rapidly broke. In the past, people had only known me as an outsider. After 2001, different NGOs, religious groups and government officials regularly visited the village. In both 2001 and 2003, I saw people busy rebuilding their lives and livelihoods and also immersing themselves with the details of compensation packages both from the state and NGOs (see Mehta 2001). Simpson (2007) refers to this period as the second earthquake, where Kutchis voiced deep concern and disaffection with the rebuilding process and also with the treatment from mainland Gujarat. Some even called for an independent and autonomous Kutch, which had been the case before India's independence when Kutch was a princely state.
In 2006, Kutch was likened to Singapore and was considered to be the engine of Gujarat's doubledigit growth (Simpson 2007). Indeed, postearthquake, Kutch became a construction site, not just due to the rebuilding process but because of the rapid inflow of capital, industries and people from outside. Simpson refers to this as Kutch's 'industrial revolution' (2007: 935). After the earthquake, the government of Gujarat introduced the 'Incentive Scheme 2001 for Economic Development of Kachchh district', in order to make 'the economic environment of Kachchh district live' (quoted in Simpson 2007: 935). This resulted in industrial development of vast proportions, helped no doubt by both excise and tax concessions for new industrial activities until 2005. The creation of special economic zones (SEZs) near the ports of Mundra and Kandla has also contributed to this rapid industrial development. The changes in the region have been remarkable as a result. Villages have been transformed to peri-urban areas. Sleepy rural areas have been transformed by factories, office blocks and four-lane highways, shopping centres and polluting industries.

The sustainability of this growth is questionable. Despite provision for pollution control, in reality the natural environment of Kutch, which has always been fragile, may well be under threat. This is due to accelerated mining activities, polluting chemical industries and increasing levels of air and water pollution. The mangroves around Mundra have vanished and groundwater continues to be depleted at a rapid rate. Wellpaid jobs have largely gone to outsiders and the locals have been hired as menial labour (Haresh Dholakia and Dinesh Sanghvi, pers comm). Land prices have sky-rocketed in some parts of Kutch.

My research area there, however, remains unaffected by these rapid changes and continues to be considered highly 'backward', with no new industrial development. But there have been massive changes in infrastructural development. In 1995-6 women and girls walked several kilometres for water with heavy earthen pots, and water was a constant source of conflict and worry in Merka. There was no electricity and the nearest phone was a 30-minute bus ride away. Today, every house has fans and electricity. Most have access to drinking water due to the introduction of piped water from the controversial and distant Sardar Sarovar (Narmada) Project (SSP) and there are 
many mobile phones in the village. Pastoralists benefit from a dairy in the village and can now coordinate their migratory routes by mobile phone. There is now a four-lane highway near the village. These are remarkable changes within a few years.

While those who lost their loved ones will never recover or forget the earthquake, most others seemed to have moved on and recovered from the trauma that I witnessed in 2001. They have rebuilt their homes and are satisfied with the compensation that they have been given. The village has grown considerably and the same is true for the district capital, Bhuj. In fact, due to the earthquake, a very remote and neglected region has leapfrogged several decades and has experienced 'development' in a way that otherwise would not have been possible. This is because a range of players (the district and state government, outsiders, diaspora Kutchis, etc.) were determined to rebuild Kutch, and Kutch perhaps stands out as an example of how a natural catastrophe crisis provided a means to both restore and enhance regional development.

\section{The uneven impacts of modernity and development}

But development in Kutch remains mixed and uneven. Education levels are very low in the village, and schools rarely educate children sufficiently to enable them to read and write. Girls still have very low literacy rates. Gender violence appears to be increasing and the veiling and segregation of women continues. A study conducted by NGOs in Kutch and Saurashtra recorded that some 89 per cent of women in Kutch and Saurashtra reported undergoing some kind of domestic violence. It also noted that not only have crimes increased, but the nature of domestic violence has become more complex and intensive (OneIndia 2007).

I did not notice many changes in the caste and feudal inequalities which had shocked me when I first came to the village. Many parts of Kutch remain highly feudal, traditional and unequal. The increasing connectivity and encounters with modernity have not led to a change in attitudes and values that challenge the status quo and call for social and gender equality and a more just society. These are not values that people espouse, apart from a few critically minded people. In the village, the lower castes, as well as some women and girls who acknowledge discrimination, continue to feel powerless to challenge social customs and dominant practices. An NGO worker feels that dominant notions of the success of Gujarat's economic growth and in Kutch's recent infrastructural development mean that very few people believe things still need to be done: donors do not feel the need to invest in issues concerning social and economic justice in Gujarat and Kutch. Thus, the needs and interests of socially discriminated groups and minorities are ignored or even trampled on.

Chief Minister Narendra Modi, who encouraged and did nothing to stop the pogroms against Muslims in Gujarat in 2002, remains highly popular and is seen to be responsible for the Gujarat miracle and its double digit growth rate. Kutch is a highly syncretic society with a high proportion of Muslims (40 per cent) and it borders Sind in Pakistan. It never before witnessed such pogroms or discrimination and yet Kutchis seem to credit Modi with many of the positive changes witnessed in recent years. A few, like the retired politician Kundenlal Dholakia, criticise him for making Gujarat burn and the minorities suffer, but most remain silent about the 2002 riots. The state machinery appears to have successfully manufactured consent towards its sectarian and anti-Muslim politics.

The changes after the earthquake have also led to a decline in traditional crafts. In the late 1990s, Kutchi homes in Merka were stunning. Walls were bedecked with white clay mirror work and embroidery and grain was stored in extraordinary earthen pots. Today, this is considered too labour intensive and very few people know how to decorate their houses in the traditional way. The mud walls collapsed in the earthquake and the rebuilt houses have cement and ceramic tiles (considered to be modern and desirable), rather than clay and mud. They are fiercely hot in the summer and do not provide the same refuge from the desert heat as the traditional homes. Women and girls do not seem to be engaging in embroidery work in the same way as before, though some say that they would like to earn money through embroidery work and were hoping for an NGO to provide such opportunities. The beautiful crafts of Merka seem to be on the decline.

Many pastoralists are giving up their traditional way of life because of the shrinking commons 
and unsympathetic government policies. The cost of mutton has gone up but there is no demand for wool, so they are not selling as many sheep as before (interview with Rabari herder, May 2010). Consequently, they are becoming agricultural labourers, making them very dependent on the largesse of patrons and the landed, or they leave the village altogether and take up casual employment in urban centres. Dryland and small farmers continue to feel highly vulnerable due to the droughts which take place every few years. Rainfall continues to be erratic and in the past two years, was not frequent, so there is little grain in storage and all grain has to be bought from the shop. A few of my close friends had left the village to work as watchmen and casual labourers in Gandhidham.

The landless feel that livelihoods in the village are on the decline. Quarrying work is no longer allowed by the government. While rural employment guarantee schemes assure the poor and landless of employment during droughts, they have not led to the mitigation of scarcity conditions or the long-term drought-proofing of Kutch. Gangabhai, a 52-year-old farmer, with 30 acres of land said: 'We would like to have a green village all the year round and not be exposed to the vagaries of nature. This is the second consecutive drought and all our hard work and money may well be lost this year'. Several other livelihoods are also under threat, for example, traditional livelihoods in the salt marshplains. Thus, despite impressive or considerable economic growth in Kutch, the spread of gains has not been equal; rather, inequalities seem to be increasing.

\section{Imaginaries of development and the need for reimagining}

Kutchis have traditionally felt a sense of deep inadequacy due to the remoteness of their land; the difficult climate and conditions; the constant battle with water scarcity; and neglect on the part of mainstream Gujarat. There is also a tendency of Kutchis to downplay the strengths of indigenous culture, knowledge and systems and to seek 'modern' ways of doing things, which in reality may not be very appropriate for the region. For example, traditional waterharvesting methods continue to be ignored. Instead, they wait for distant water wonders in the form of canals and Narmada water, which may never come to Kutch and which may never alleviate water scarcity problems in an equitable way (Mehta 2005). While drinking-water problems have been addressed to a certain degree by the Narmada pipeline, it is still highly unlikely that irrigation water from the Narmada project will reach Kutch in the near future. This is one of the main reasons why the controversial project was sanctioned. In fact, the state machinery has systematically manufactured consent in Gujarat around infrastructure-led development epitomised by the large dam (Mehta 2005). In doing so, they have stamped out dissent and all kinds of explorations of alternatives. Thus, getting irrigated water from the Narmada river still remains an unattained dream for many farmers in Merka, and most people in Gujarat view the project as Gujarat's lifeline. But very few in Kutch and Gujarat question whether such dam-based development, that has displaced millions, is highly uneven in its distribution of benefits and is beset by cost and time overruns, is appropriate for Gujarat and Kutch.

The following is a minority view from a critical NGO worker in Kutch, who laments that there is no space for critical voices in Gujarat:

There's been a lot of changes in Kutch but they are not reaching the poor. The arrival of Narmada water has led to a false sense of complacency. It has prevented the promotion of rainwater-harvesting, so urgently required in the desert environment. People think that Narmada will solve all their problems. In reality, Dalits, women, tribals and minorities are all suffering. But this is the hidden side of Gujarat that nobody wants to recognise. Anybody who raises these issues is condemned as anti-Gujarat.

Thus, there are a few and lone alternative voices to mainstream development but these voices tend to be silenced due to the power of dominant players and their perspectives.

The money pumped into Kutch by its nonresident daughters and sons has led to many temples, trusts, new assertions of identity (e.g. global Patelism and a new Swaminarayan Temple in Bhuj), but it has not tackled unequal social and gender relations. As a Bhuj-based journalist put it:

\footnotetext{
Kutch has changed dramatically physically but there have been very few changes in values and attitudes. In fact, people may even have become more closed and
} 
narrow minded due to insecurity. There is a growing interest in religion and maybe even a crisis in identity. Casteism, religious sentiments and regionalism are on the rise!

In the village, many people imagine, dream and hope of a better life for themselves and their children. Naviben, a 53-year-old Dalit wants the state or an NGO to introduce some schemes to engage women in embroidery or other gainful employment in the village, so as to avoid seasonal migration to urban centres. Ambabhai, a 43-year-old father, along with many other parents, wants better schooling in the village so that their children can actually learn how to read and write and not just 'hang out in school and eat the midday meal'. They also urgently want a middle and secondary school that goes beyond the 7 th Standard, that will enable children to go to school in their own village or nearby, rather than have to be miserable in an inadequate school $100 \mathrm{~km}$ away. Pastoralists like him are increasingly caught between their traditional lifestyles, which are increasingly unviable, and modernity. Shanta, a 26-year-old deserted woman, wants to have the right to raise her son. She was married into a rich family that lived several hundred kilometres away but her husband deserted her after he found another woman. She returned home with her son. Her father, however, buckled under social pressure and sent the son back to live with his father's family. She would like to go to court to claim custody but it is unlikely that she will get support from her family to do so. She also refuses to remarry (something her father would organise

\section{References}

Bhat, Rajesh (undated) Kutch Goes Global, www.sooperarticles.com/print/Kutch-goesglobal-707671.html (accessed 1 September 2010)

Buncombe, Andrew (2010) 'India's Middle Class Drives Economic Growth of 8.8\%', The Independent, 1 September

Green, D.; King, R. and Miller-Dawkins, M. (2010) The Global Economic Crisis and Development Countries: Impact and Response, Oxfam Research Report, Oxford: Oxfam Mehta, Lyla (2005) The Politics and Poetics of Water: Naturalising Scarcity in Western India, New Delhi: Orient Longman for her) and instead is determined to wait until her son is older when, she is convinced, he will come back for her. While poor people want different aspects of their lives to change, none of this constitutes any radical reimagining of development. As Shanta's case shows, even though she is prepared to fight for her son, gender stereotypes and injustices prevent her from doing so. Largely, Kutch has remained traditional and feudal. Education is not widespread, deeply entrenched prejudices remain intact and development is largely conceptualised in terms of economic growth.

In sum, my revisit to Kutch after seven years revealed that the presence of the GFG was not overtly evident in the region. It had recovered from the massive earthquake of 2001 and was undergoing rapid economic growth. But this economic growth had not translated to overall human development and wellbeing and much of this development is not environmentally sustainable or socially just. Gujarati/Kutchi society has never allowed for much dissent or radical thinking which may explain the lack of imagination around development. As the case of dam-based development reveals, dominant paradigms of development remain unquestioned and any criticism is condemned as anti-Gujarati. While recent events in Kutch have led to positive changes for many, there remain several unknowns and potential negative impacts in terms of environmental sustainability. They have not led to any radical reimaginings around equity or gender and social justice.

Mehta, L. (2001) 'Reflections on the Kutch Earthquake', Economic and Political Weekly 4, August 2001, XXXVI: 2931-7

OneIndia (2007) Domestic Violence against Women on Rise in Gujarat: NGO Study, www.news.oneindia.mobi/2007/10/26/ 470945.html (accessed 1 September 2010)

Simpson, Edward (2007) 'State of Play Six Years after the Gujarat Earthquake', Economic and Political Weekly 42.11: 932-7 